\title{
Becoming a Landlord: Strategies of Property-Based Welfare in the Private Rental Sector in Great Britain
}

\author{
Adriana Mihaela Soaita ${ }^{1}$ \\ Centre for Housing Research, University of St Andrews, St Andrews, UK
}

Beverley Ann Searle

School of Social Sciences, University of Dundee, Dundee, UK

\section{Kim McKee}

Centre for Housing Research, University of St Andrews, St Andrews, UK

\section{Tom Moore}

Town and Regional Planning, University of Sheffield, Sheffield, UK

Accepted for publication in Housing Studies published by Taylor and Francis. The final published version is available at: https://doi.org/10.1080/02673037.2016.1228855

${ }^{1}$ Corresponding author: Adriana Mihaela Soaita, Centre for Housing Research, University of St Andrews, St Andrews, Buchanan Gardens, KY16 9LZ, UK, Tel.: +44 (0) 7435580914 email: asoaita@yahoo.com 


\section{AbSTRaCT}

Ongoing neoliberal policies have realigned the links between housing and welfare, positioning residential property investment-commonly through homeownership and exceptionally also through landlordism — at the core of households' asset-building strategies. Nonetheless the private rented sector (PRS) has been commonly portrayed as a tenure option for tenants rather than a welfare strategy for landlords. Drawing on qualitative interviews with landlords across Great Britain, we explore landlords' different motivations in engaging in landlordism; and the ways in which their property-based welfare strategies are shaped by the particular intersection of individual socioeconomic and life-course circumstances, and the broader socioeconomic and financial environment. By employing a constructionist grounded approach to research, our study contributes to a more nuanced understanding of the different ways that asset-based welfare strategies operate within the PRS. We draw attention to an understudied nexus between homeownership and landlordism which we argue represents a promising route for future research.

Keywords: private rental sector; landlords; asset-based welfare; property; inequality; United Kingdom. 


\section{Introduction}

Since 2000 the share of the PRS in the UK housing stock has doubled, accounting for 19 percent of all dwellings in 2014 (GOV.UK 2016). ${ }^{1}$ This represents an outstanding growth among OECD countries even though comparatively the size of the PRS is not particularly large but comparable to that in Austria, Belgium, Norway and Sweden for instance, and much smaller than in Australia, Germany, Switzerland and US (Scanlon and Kochan 2011). The PRS growth occurred concurrently with a 15-year decline in homeownership rates, which currently stand at their 1987 levels, and a three-decade fall in the share of social housing. These tenure shifts reflect wider socioeconomic and political changes in the UK (Crook and Kemp 2010; Malpass 2005).

A long-term neoliberal governmental agenda of deregulation clearly encouraged the supply of privately-rented accomodation as did the contraction of other rental options through the Right-to-Buy (RtB) policies. The PRS grew tentatively during the 1990s and robustly after 2000 given the availability of Buy-to-Let (BtL) mortgages since $1996^{2}$. However, mediumterm developments were consequential to the growth of the PRS, particularly those taking place in labour markets. Higher education expansion, employment insecurity and wage inequality have resulted in an increasing demand from students, mobile professionals, international migrants and those wishing but unable to buy their first home (Ball 2010; Hughes and Lowe 2007). Furthermore, high growth in house values has made residential investment attractive to those individuals who could afford to buy as did a general social policy shift from the socialisation to the individualisation of family welfare in the UK (Langley 2004; McKee 2015).

While the role of homeownership and housing wealth has been recognised as central to households' strategies of providing for their family welfare in the UK (McKee 2012; Searle and McCollum 2014; Smith and Searle 2010) and elsewhere (Doling and Elsinga 2012; Ronald 
2008; Ronald and Elsinga 2012), the subject of landlordism has not entered this debate until recently (Ronald et al. 2015). Critically, the PRS has been cast in terms of a tenure option for tenants rather than a welfare strategy for those engaged in letting activities; crucially, landlords' voices were missing from these analyses (Ball 2010; Crook and Kemp 2010; Hughes and Lowe 2007; Lloyd 2013; Lord et al. 2013). Key questions thus arise regarding landlords' motivations for engaging in the PRS and the ways in which their property-based welfare strategies are shaped by the particular intersection of individual socioeconomic and life-course circumstances, and the broader socioeconomic and financial environment. To this we aim to contribute by analysing 34 qualitative interviews conducted with landlords across Great Britain (GB).

The relevance of our study is three-fold. First, we aim to contribute to a more nuanced understanding of the different ways that asset-based welfare (ABW) strategies operate within the PRS. The sector has become an increasingly crucial tenure for many and there is social pressure for the need to find better ways to harmonise the interests and welfare of those providing and those needing a privately-rented home (CCHPR 2012; Rugg and Rhodes 2003; Scanlon and Kochan 2011). Second, our inquiry is important for social policy questions within and beyond the UK; notwithstanding its British focus, our study has international relevance given that similar property-based realignments between housing and welfare have taken place elsewhere (Ronald and Doling 2012). Third, by employing a constructionist grounded approach to research (Charmaz 2014), we substantiate an understudied nexus between homeownership and landlordism, mediated through taken-for-granted beliefs and meanings, which we argue constitutes a promising route for future research.

The paper follows in five sections. First, the theoretical approach of ABW within which we have framed our research question is introduced. Second, we present landlords' privileged socioeconomic profiles in comparison with other groups, and the implications of this to 
socioeconomic inequality. Third the methodology of our explorative study is presented. Fourth, by differentiating between landlords' investment aim and between small and large portfolios, we show that landlords' property-based welfare strategies differ; they have different motivations to acquire, and ascribe different uses for their property wealth according to their overall wealth portfolio; and the intersection between their personal circumstances and the broader environment may create both positive and negative synergies. Finally, we reflect on our key findings and their implications for policy and further research.

\section{Tenures, Assets and Welfare}

The major role of the state in the tenure shifts from around 80 percent private renting in 1920 to 70 percent homeownership in 2001, and the recent revival of the PRS have been well documented (Hamnett 1999; Hughes and Lowe 2007; Kemp 2015; Malpass 2005). These shifts were mediated through changing political agendas, public policies, and symbolic practices which have shaped the (re)alignment between political-economy, the housing system and social welfare. Together with other Anglo-Saxon countries, the UK is now recognised as being an exemplar of the (neo)liberal residential and welfare regimes (Esping-Andersen 1990; Kemeny 1981; Schwartz and Seabrooke 2009), being characterised by deregulated financial markets; mortgaged homeownership; and a move from the socialisation to the individualisation of welfare (with social support being increasingly restricted and conditioned).

These tenure shifts were paralleled by exceptional growth in house prices, particularly after 2000 (Figure 1). By the concomitant construction of credit abundance through the 
Figure 1. Movements in house values and tenures (the UK)

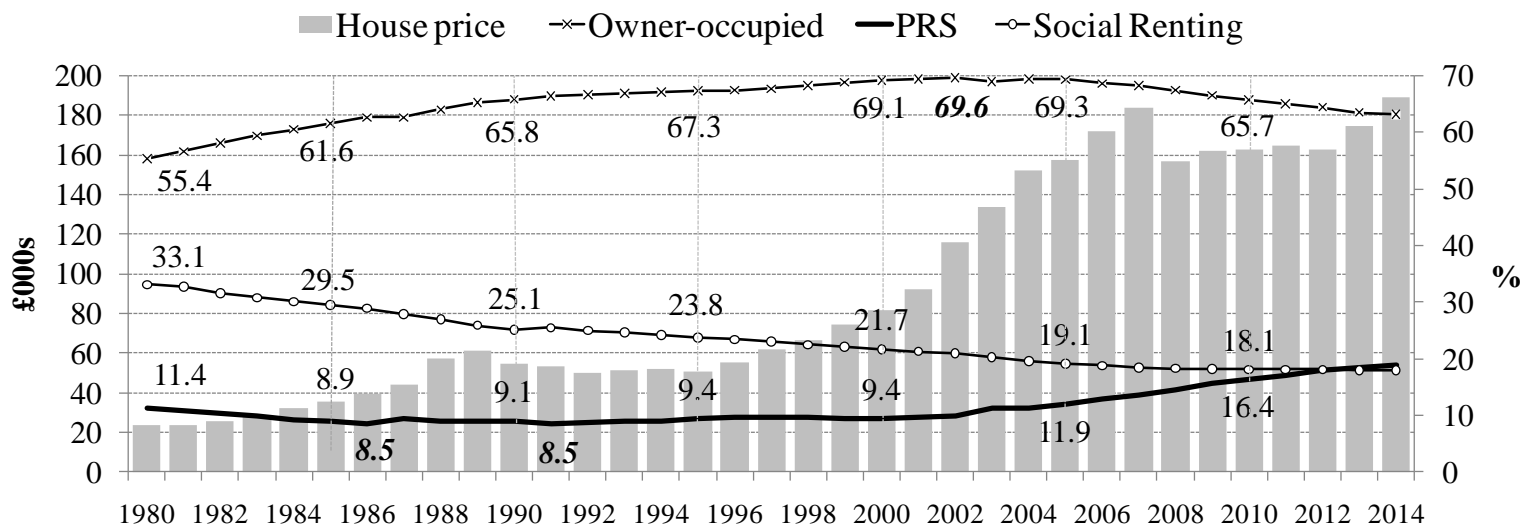

Source: authors' analysis (Nationwide 2015; ONS 2015 dwst1b-gb)

financialisation of housing markets (Smith and Searle 2010) and housing scarcity through historic lack of supply and unequal distribution (Barker 2004; Dorling 2014), house values on average increased nine-fold during 1980-2013. Consequently households increasingly saw homes as assets and property ownership as a means of asset-building.

The role of homeownership in supporting the private provision of family welfare along the life-course has been scrutinised under the ABW approach (Doling and Elsinga 2012; Doling and Ronald 2012; Fox O'Mahony and Overton 2014; Ronald and Elsinga 2012; Ronald and Doling 2012; Toussaint and Elsinga 2009). Reliance on, and ways of tapping into, the wealth of one's home through rent-free living, downsizing or specialised mortgages was shown to be valued by households across countries but practices differed between and within countries reflecting the particular intersection of housing systems, social policies, financial markets and households' socioeconomic means and socio-cultural values.

Certainly, the expansion of homeownership opened an avenue for asset accumulation for many households. For instance in the UK, average gross capital gains between 1990 and 2015 reached around $£ 148,000$ nationally; $£ 178,000$ in the South East; and $£ 74,000$ in the North East (Soaita and Searle 2016). Likewise downsizing from a detached house to a 
bungalow produced on average $£ 100,000$ in 2014 (Lloyds Bank 2015). Patterned by geography, returns were greater for higher than lower income households though most low income homeowners accumulated more assets than their renting counterparts (Hills et al. 2010). Nonetheless, the approach of building financial security via homeownership remains challenged by the unequal distribution of housing wealth across regional/local markets, between boom-and-bust cycles, and across socioeconomic groups and age cohorts; and benefits are not guaranteed (Cramer and Shanks 2014; Langley 2009; McKee 2012; Searle and McCollum 2014; Smith et al. 2009; Smith and Searle 2010). Crucially, in cases of income falls, negative equity or repossession both the 'meaning' and the physical 'place' of home can be jeopardised (Fox 2007).

Surprisingly, the unique welfare possibilities offered by landlordism have not entered the ABW debate until recently (Ronald et al. 2015). On the one hand, landlordism may safeguard one's own place of home from a need to liquidate housing wealth, which has been shown to be a key disadvantage of a reliance on homeownership as a safety-net. On the other hand, it might facilitate building an asset through the flow of rental income and further capital gains. The privately rented dwelling thus becomes a means of property-based welfare for landlords as well as a home to tenants.

Langley (2006 pp.922) convincingly argued that through policy discourses and a mix of regulatory arrangements, governments aimed to construct workers as 'investor subjects' whose knowledge, responsibility and pro-active engagement in investment markets promised the individual provision of personal/family welfare. While most individuals remained reluctant or unable to engage in an ever more complex and uncertain investment landscape, the growth of the PRS draws attention to the fact that some were increasingly willing and able to navigate financial and housing markets in order to invest in the tangibility and familiarity of (additional) residential property (Dorling 2014). Yet the potential nexus between homeownership and 
landlordism may cast the latter as an extrapolation of the internalised orthodoxy of homeownership rather than a business activity; a matter of belief rather than one of accounting. While substantiating this potential nexus requires empirical work, analyses of the sociallyconstructed nature of tenure (Flint 2003) and housing preferences (Bourdieu 2005), the internalisation of homeownership (Gurney 1999) and of widespread beliefs in ever-increasing house values (Soaita and Searle 2016) suggest that some individuals' attraction to landlordism may be grounded in existing dispositions of seeing one's home as a means of wealth accumulation.

We endorse that such dispositions, including meanings, values and beliefs, are causative of action; this interpretative and critical-realist ontological endorsement (Bhaskar 1989; Boudon 2001) frames our research questions and our analytical approach — as we will show later. But we also maintain that meanings are socially constructed within various systems of power (particularly the family and the state). Linking interpretative, critical-realist and social-constructionist approaches is not unusual in sociological thought, most notably in Bourdieu's theory of practice (Bourdieu 1977, 1990, 1998). ${ }^{3}$ Given space constraints, we shall assume that most readers of this journal are familiar with his elaborated conceptual framework. We concisely outline below some key concepts relevant to our own discussion.

Bourdieu (1985, 1989) argues there is a match (homology) between dispositions (habitus) — which include systems of beliefs, meanings and values — and positions in the social space or in particular domains (fields), e.g. housing and landlordism. For Bourdieu, social positions were defined according to agents' capital endowments in terms of both overall volume and the composition of capital. He commonly differentiated between four interlinked and mutually convertible forms of capital: 
- Cultural capital, which exists in an embodied state (long-lasting dispositions, e.g. habits-of-mind, skills, manners, tastes which form the habitus), an objectified state (cultural goods) and an institutionalised state (educational/professional qualifications);

- Social capital, which represents material or symbolic profits resulting from membership in a group;

- Economic capital, seen as the most consequential form of capital in modern societies, from which the other two can be derived (with an effort of self-transformation);

- Finally, any of these three forms can function as symbolic capital.

Bourdieu never ceased to emphasise that individuals are unevenly endowed with each of these forms of capital; not only does the accumulation of any of these forms of capital take time to occur, but it is cumulatively dependent on one's previous capital possession. Occupying different socioeconomic positions, individuals thereby unequally compete for ownership of distinctive types of housing. Tenure is thus not just a socially constructed, relatively stable and historically enduring social institution (Ruonavaara 2012) but an essential device in the reproduction (and display) of advantage and disadvantage. Indeed, homeownership has been shown to reinforce the existing socioeconomic inequalities between owner-occupiers and tenants across lifecycle (DCLG 2010; Hills et al. 2010; Hills et al. 2013). It follows that ownership of multiple housing assets intensifies inequality within the property-haves and between them and the property-have-nots.

\section{Landlords' Socioeconomic and Property Profile}

Until recently data on landlords have been sparse. For instance, Lloyd (2013) and Lord et al. (2013) presented an analysis of the socioeconomic profile, savings and investment strategies of individual landlords in GB compared to other social groups ${ }^{4}$. Focusing on England ${ }^{5}$, DCLG 
(2011) compared the socioeconomic profiles of individual and institutional landlords along the same lines. In this paper we focus exclusively on private individual landlords (henceforth termed landlords) and their lets (henceforth termed PRS stock/dwellings/lets). ${ }^{6}$ In England, 89 percent of all landlords were private individuals, owning 71 percent of the PRS stock in 2011 (DCLG 2011) ${ }^{7}$. Across GB, landlordism has expanded from one to three percent of all adults aged 16-and-over between 1991 and 2008 while remaining nonetheless highly concentrated (Lord et al. 2013); of these, about two-thirds expected to stay in the sector for the long-term. DCLG (2011).

Tables 1 and 2 indicate compounding advantages along the life-course for landlords in terms of their endowment with cultural, economic and symbolic capital. In comparison with

Table 1. Comparative socioeconomic and demographic profile of landlords in Great Britain

\begin{tabular}{|c|c|c|c|c|c|c|c|c|c|c|}
\hline & \multirow{2}{*}{$\begin{array}{l}\text { Grew up in } \\
\text { an owned } \\
\text { home }(\%)\end{array}$} & \multirow{2}{*}{$\begin{array}{c}\text { Degree } \\
\text { or more } \\
(\%)\end{array}$} & \multirow{2}{*}{$\begin{array}{c}\text { In } \text { work }^{4} \\
(\%)\end{array}$} & \multirow{2}{*}{ 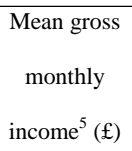 } & \multirow{2}{*}{$\begin{array}{c}\text { Enough } \\
\text { income to meet } \\
\text { outgoings (\%) }\end{array}$} & \multicolumn{2}{|c|}{$\begin{array}{c}\text { Net financial } \\
\text { assets }(\mathfrak{f})\end{array}$} & \multirow{2}{*}{$\begin{array}{c}\text { Married or } \\
\text { cohabiting } \\
(\%)\end{array}$} & \multicolumn{2}{|r|}{ Age } \\
\hline & & & & & & Mean & Median & & & between: \\
\hline Landlords $^{1}$ & 76 & 41 & 77 & 2,868 & 78 & 75,103 & 20,500 & 87 & 49 & $35-65$ \\
\hline All adults ${ }^{3}$ & 55 & 22 & 59 & 1,945 & 63 & 22,981 & 2,300 & 61 & 46 & $\mathrm{n} / \mathrm{k}$ \\
\hline PRS tenants & 64 & 26 & 65 & 1,676 & $\mathrm{n} / \mathrm{k}$ & 9,506 & 398 & 49 & 37 & $16-44$ \\
\hline
\end{tabular}

Source: Lord et al. (2013) and Lloyd (2013) based on Wealth and Asset Survey, wave 2 (2008-2010)

${ }^{1}$ This excludes landlords who are renters themselves ( $8 \%$ of all landlords) or who receive rent exclusively from lodgers. ${ }^{2}$ This refers to non-landlord homeowners. ${ }^{3}$ All population aged 16 and over. ${ }^{4}$ Employed and self-employed. ${ }^{5}$ Only for those employed. 
Table 2. Comparative property wealth portfolios of landlords in Great Britain

\begin{tabular}{|c|c|c|c|c|c|c|c|c|c|c|c|c|c|}
\hline & \multicolumn{5}{|c|}{ Own home (\% if not otherwise stated) } & \multicolumn{2}{|c|}{ Mortgage (\%) } & \multicolumn{3}{|c|}{ Portfolio size (\%): } & \multirow{2}{*}{$\begin{array}{c}\text { All } \\
\text { equity }\end{array}$} & \multicolumn{2}{|c|}{ All rent received $\mathrm{pm}$} \\
\hline & $\geq 3$ spare & Mean & Owned & Debt/val & Equity & Not a & A heavy & 1 & $2-3$ & $\geq 4$ & & Mean & Median \\
\hline & bed's & value (f) & outright & ue $\geq 60 \%$ & $\geq 175 \mathrm{k}$ & burden & burden & let & lets & lets & $($ mean $£)$ & & \\
\hline Landlords $^{1}$ & 20 & 188,200 & 32 & 41 & 39 & 58 & 7 & 72 & 22 & 6 & 480,000 & 1,493 & 500 \\
\hline Homeowners $^{2}$ & 11 & 120,000 & 45 & 34 & 21 & 49 & 14 & $\mathrm{n} / \mathrm{a}$ & $\mathrm{n} / \mathrm{a}$ & $\mathrm{n} / \mathrm{a}$ & $\mathrm{n} / \mathrm{a}$ & $\mathrm{n} / \mathrm{a}$ & $\mathrm{n} / \mathrm{a}$ \\
\hline All adults ${ }^{3}$ & 8 & 130,500 & 30 & 32 & 24 & 49 & 14 & $\mathrm{n} / \mathrm{a}$ & $\mathrm{n} / \mathrm{a}$ & $\mathrm{n} / \mathrm{a}$ & $\mathrm{n} / \mathrm{a}$ & $\mathrm{n} / \mathrm{a}$ & $\mathrm{n} / \mathrm{a}$ \\
\hline
\end{tabular}

Source: Lord et al. (2013) and Lloyd (2013) based on Wealth and Asset Survey, wave 2 (2008-2010)

${ }^{1}$ This excludes landlords who are renters themselves ( $8 \%$ of all landlords) or who receive rent exclusively from lodgers. ${ }^{2}$ This refers to non-landlord

homeowners. ${ }^{3}$ All population aged 16 and over. 
homeowners and the whole population, landlords are more likely to grow up in an owneroccupied home; have higher education levels; be in work; have higher income, more financial wealth and larger homes. Consequently, Table 3 shows that landlords' ability to save/invest their economic capital across various financial products is also higher. Crucially, landlords are more likely to believe that property is the best way to invest and the safest way to finance retirement, which suggests a causative link between beliefs and actions. Overall, Lloyd (2013 pp.20) appreciated that landlords were in a privileged position even though only a few 'could be considered "super rich". Given that only 20 percent of PRS tenants received housing benefits and that landlords were significantly better off than their tenants, he argued that the functioning of the PRS increases economic inequality through transfer of private wealth from the least to the better off in society; and from the younger to the older cohorts - as the demographic profiles in Table 1 indicate.

If we accept that through capital gains homeownership reinforces existing inequalities between property-haves and property-have-nots (Hamnett 1999; Hills et al. 2010), it follows that landlordism magnifies this effect by the combined means of capital gains and rental income. The larger a rental portfolio is, the greater the effect on economic inequality is.

Table 3. Comparative investment strategies and opinions of landlords in Great Britain

\begin{tabular}{|c|c|c|c|c|c|c|c|c|c|c|}
\hline & \multicolumn{2}{|c|}{ Saved over past $2 \mathrm{y}(\%)$} & \multicolumn{3}{|c|}{ Has (\%): } & $\begin{array}{l}\text { Property is the } \\
\text { best way to }\end{array}$ & \multicolumn{4}{|c|}{ Financing retirement (\%) } \\
\hline & $\begin{array}{c}\text { Any } \\
\text { amount }\end{array}$ & $\begin{array}{l}\text { More than } \\
£ 5,000\end{array}$ & ISA & $\begin{array}{l}\text { Life } \\
\text { cover }\end{array}$ & $\begin{array}{c}\text { Shares (not } \\
\text { with employer) }\end{array}$ & $\begin{array}{l}\text { best way to } \\
\text { invest (\%) }\end{array}$ & $\begin{array}{c}\text { Eligibility } \\
\text { for occup. } \\
\text { pension }\end{array}$ & $\begin{array}{l}\text { Cannot } \\
\text { afford to } \\
\text { contribute }\end{array}$ & $\begin{array}{l}\text { Safest by } \\
\text { pension } \\
\text { scheme }\end{array}$ & $\begin{array}{l}\text { Safest by } \\
\text { property }\end{array}$ \\
\hline Landlords $^{1}$ & 68 & 21 & 61 & 38 & 31 & 63 & 39 & 18 & 26 & 49 \\
\hline Homeowners $^{2}$ & 57 & 11 & 54 & 30 & 18 & 32 & 41 & 32 & 43 & 20 \\
\hline All adults ${ }^{3}$ & 48 & 9 & 41 & 22 & 12 & 32 & 29 & 34 & 36 & 21 \\
\hline PRS tenants & 38 & 9 & 24 & 11 & 3 & $\mathrm{n} / \mathrm{k}$ & $\mathrm{n} / \mathrm{k}$ & $\mathrm{n} / \mathrm{k}$ & $\mathrm{n} / \mathrm{k}$ & $\mathrm{n} / \mathrm{k}$ \\
\hline \multicolumn{11}{|c|}{ Source: Lord et al. (2013) and Lloyd (2013) based on Wealth and Asset Survey, wave 2 (2008-2010) } \\
\hline
\end{tabular}


However, Table 2 shows that most landlords owned just one or two lets. Rental income varied with one quarter receiving less than $£ 300$ in monthly rent and another quarter getting over $£ 900$. However, rental income was commonly less than a quarter of landlords’ wages; and for only one-third of landlords was the rental income higher than 80 percent of their total income. This indicates that landlordism was a sideline activity for many (DCLG 2011; Lord et al. 2013).

While these data demonstrate inequality between groups, they also evidence existing inequality among landlords. DCLG (2011) showed that in England, one percent of landlords owned 10 or more properties but they controlled 13 percent of the stock. ${ }^{8}$ Conversely, some struggled (NLA 2013; Wallace and Rugg 2014). By several measures, about 12-15 percent of all landlords could be considered financially exposed ${ }^{9}$ (Clarke 2016; Lord et al. 2013; Wallace and Rugg 2014). This is particularly important because landlords' financial resilience impacts on their own and their tenants' welfare. Quantitative data thus evidenced landlords' diversity regarding their socioeconomic, demographic and property profiles. However, qualitative insights can contribute to a better understanding of landlords' motivations to engage in property-based welfare and how their strategies relate to the intersection of particular socioeconomic and life-course circumstances and the broader environment. To this we aim to contribute after we present the methodological design of our study next.

\section{Research design}

Data were drawn from two work streams of the project 'Mind the (Housing) Wealth Gap'. These focused on the housing experiences of people aged 18-35 and 35-65. Regarding the former, eight case studies were drawn in order to examine differences between rural/urban areas and particular housing/labour market associations. ${ }^{10}$ Following a purposive sampling 
strategy, during April 2013-October 2014 we conducted 10 on-line focus groups with 33 participants and 31 semi-structured telephone interviews (with two respondents overlapping). In total 62 people took part. Regarding the 35-65 year-olds, we conducted 112 semi-structured telephone interviews with owners and tenants. To obtain national coverage and a mix of socioeconomic, demographic and tenure profiles, the sample was nested in the 2012 Family Resources Survey. ${ }^{11}$ Fieldwork was conducted during June-December 2013.

In this paper, however, we report on an incidental subsample of 22 homeowners (11 outright and 11 mortgagees) who were engaged in landlordism at the time of data collection and four homeowners who did so in the past. We also draw on insights from participants planning to let out in the near future ( $\mathrm{n}=9$ of whom one was also a past landlord; eight were mortgagees and one lived with parents). This group is relevant to our qualitative inquiry since we posit values/beliefs as being causative of action. Our sample thus comprises 34 participants. ${ }^{12}$ Each GB region was represented by up to seven participants.

Data on socioeconomic, demographic and property profiles and housing history were introduced in an SPSS database for analysis in conjunction with the qualitative data. Participant notes were created after interviews and developed during data analysis. The recorded interviews were professionally transcribed; and the anonymous transcripts were coded using NVivo. Our approach to coding the textual data-and to the presentation of findings in the following section - reflected both our epistemological and ontological perspectives, and the limitations of our study. We coded thematically based on the principles of 'Constructivist Grounded Theory' (Charmaz 2014) that is inductively, in a bottom-up approach, with codes and categories being grounded in empirical evidence. This approach seeks to understand social phenomena from the participants' perspective while remaining alert to the hermeneutic and interactionist challenges to verstehen due to the inherent participants/researcher co-production of data, and the intrinsically subjective nature of data interpretation. It encourages the 
researcher to follow emergent themes and unexpected leads, such as the subject of landlordism which was not the focus of our main study. However, given the incidental nature of our sample, we recognise we were unable to achieve theoretical saturation, which would have required further and purposive data collection. Our paper remains thus explorative while bringing unique qualitative insights to an understudied subject.

Tables 4 and 5 show participants' socioeconomic profiles. The participant pool was relatively balanced across age groups; we do not report on participants aged 18-24 (n=19) for none was a landlord. Our landlords' sample shows high socioeconomic diversity, matching that evidenced by quantitative studies. The sample contains 13 participants with one rental property (72 percent, nationally) and five participants with large rental portfolios of more than 4 lets (2 percent, nationally). Likewise four participants had less than $£ 15000$ household

Table 4. Sample distribution by age groups and number of properties

\begin{tabular}{|c|c|c|c|c|c|}
\hline & $\begin{array}{l}25-34 \\
(n=42)\end{array}$ & $\begin{array}{l}35-44 \\
(n=23)\end{array}$ & $\begin{array}{l}45-54 \\
(n=42)\end{array}$ & $\begin{array}{l}55-65 \\
(n=48)\end{array}$ & $\begin{array}{c}\text { Total } \\
(n=155)\end{array}$ \\
\hline Current landlords, by: & 2 & 3 & 7 & 9 & 22 \\
\hline \multirow[t]{4}{*}{ No of lets } & 1 (x 1 let) & 3 (x1 let) & 4 (x 1 let) & 6 (x 1 let) & \\
\hline & 1 (x 2 let) & & 1 (x 3 let) & 1 ( $\mathrm{x} 3$ let) & \\
\hline & & & 1 (x 5 let) & 2 (x 6 let) & \\
\hline & & & 1 (x 13 let) & 1 (x 12 let) & \\
\hline In the past & 1 & - & 1 & 1 & 3 \\
\hline Prospective & 2 & 4 & 3 & - & 9 \\
\hline Total & 5 & 7 & 11 & 11 & 34 \\
\hline
\end{tabular}


Table 5. Sample distribution by household income (£000s)

\begin{tabular}{lllllllll}
\hline & $<£ 15$ & $£ 15-30$ & $£ 30-40$ & $£ 40-50$ & $£ 50-60$ & $£ 60-100$ & $>£ 100$ & All \\
\hline $25-34$ & - & - & 1 & - & - & 1 & - & 2 \\
\hline $35-44$ & - & - & 1 & - & 1 & - & 1 & 3 \\
\hline $45-54$ & 1 & - & 2 & 1 & - & 1 & 2 & 7 \\
\hline $55-65$ & 3 & 2 & 2 & - & 1 & - & 2 & 10 \\
\hline In the past & - & 1 & - & 1 & - & 1 & - & 3 \\
\hline Prospective & - & 3 & 1 & 1 & 1 & 3 & - & 9 \\
\hline Total & 4 & 6 & 7 & 3 & 3 & 6 & 5 & 34 \\
\hline
\end{tabular}

income whereas five participants had over $£ 100$ 000. Overall, 27 out of 34 participants had high education levels (degree or higher). We now turn to explore participants' motivations for becoming landlords and the ways in which their property-based welfare strategies are shaped by the particular intersection of their personal circumstances and the broader socioeconomic and financial environment.

\section{Landlords' property-based welfare strategies}

Following previous research (DCLG 2011; Lord et al. 2013), we differentiate between landlords' strategies based on two key dimensions (Table 6): their investment aims and the size of their portfolios. These allow us to substantiate the diversity of our participants' motivations to become landlords; their mobilisation of different forms of capital; and the way their approaches to investment link to conjectural circumstances, social positions, and the broader socioeconomic and financial environment. The columns differentiate between the investment aim of relying primarily on capital gains, rental income or both—but we also 
Table 6. Landlords' current property-based investment plans

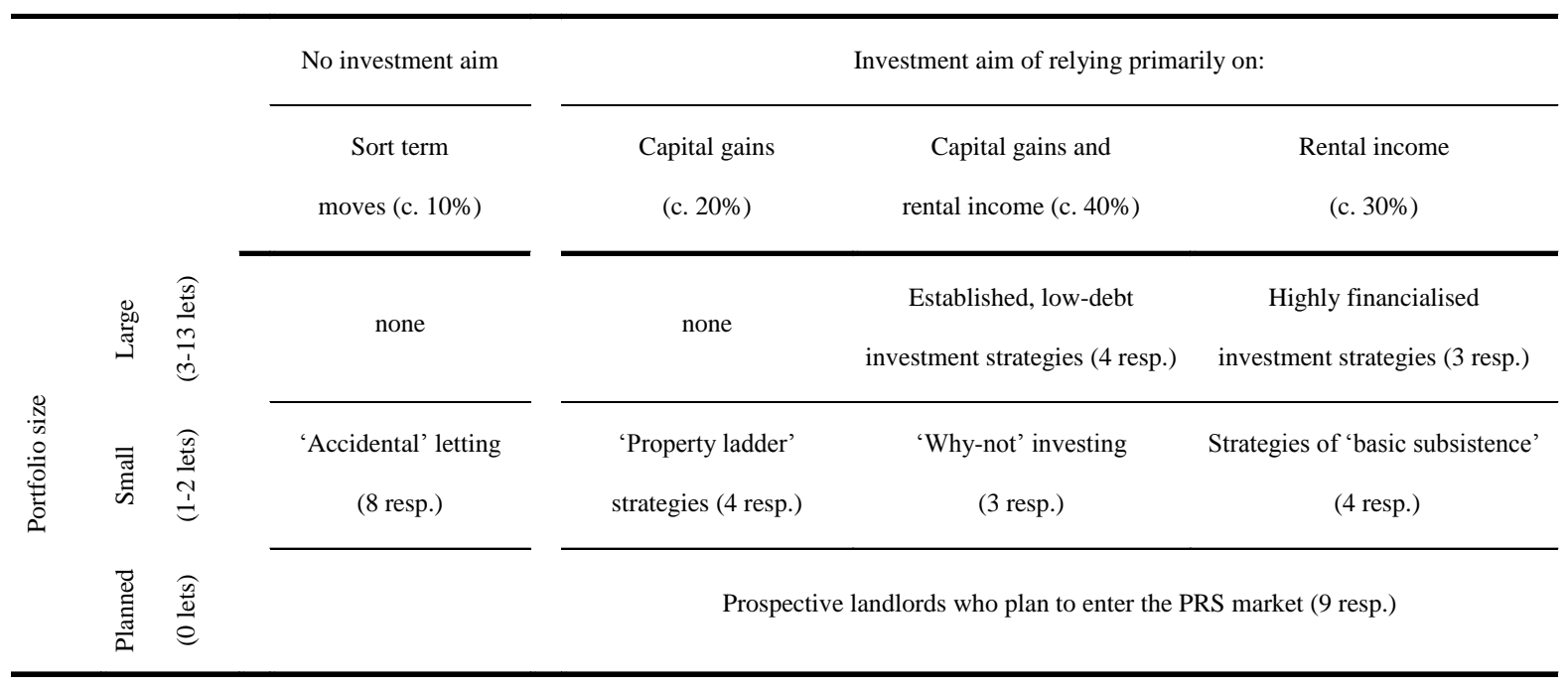

Note: The percentages in the second row brackets indicate the share of landlords which fall into these categories in Great Britain according to Lord et al. (2013). We showed in brackets the number of respondents who substantiated each analytical category (e.g. 3 resp.).

include a column for short-term moves since existing scholarship has evidenced that about 10 percent of individual landlords have no investment aims, being in the market only circumstantially (Lord et al. 2013). The rows specify portfolio sizes, distinguishing between small and large portfolios (1-2 lets and 3-13 lets, respectively, to allow for our sample characteristics). The last row refers to a group of participants who planned to engage in landlordism, who we could not ignore given our ontological perspective (i.e. beliefs being causative of action). Hence, we differentiated between seven different property-based welfare strategies, which were substantiated by our inductive, grounded approach to data interpretation. They blend a particular mix of dispositions related to welfare provision and property investment; social positions and social trajectories (the accumulation of capital along the lifecourse); and personal, conjectural circumstances. They are therefore not arbitrary; they are tailored to our research questions; but they are not exhaustive. Moreover, approaches to property-based welfare are necessarily fluid for they reflect and adapt to (unplanned) changing circumstances along the life-course. For instance, a position of letting out reluctantly given inability to sell may be reconsidered for a more strategic engagement. Likewise, while most of 
our participants were asset-builders, a few unexpectedly had to resort to their property wealth as a safety-net. We recognise, of course, that the small number of participants substantiating each strategy is a limitation of this exploratory project; nonetheless, our data were rich (with at least one interview per group lasting more than $80 \mathrm{~min}$ ).

We proceed by discussing first the strategies of small-portfolio landlords followed by those of large-portfolios. This distinction is not necessarily one between sideline/amateur and professional landlords, which could not be grounded in our data. ${ }^{13}$ If professional landlords are those deemed to derive their main source of income from their rents, then Mr AM, a oneproperty self-employed landlord on low, irregular income would qualify whereas $\mathrm{Mr} \mathrm{IH}$, a fiveproperty landlord would not for two-thirds of his regular income came from other business. If professional landlords are those deemed to employ professional services, then $\mathrm{Mr} \mathrm{DH}$, a halfproperty landlord would qualify as he used a full-service letting agency whereas Mr PL, a 12property landlord would perhaps not qualify as he was running directly his rental business, including DIY repairs and redecorations.

\section{Unplanned Moves: 'Accidental' letting strategies}

Previous research (Lord et al. 2013) evidenced that 28 percent of the rental stock was acquired with an intention other than investment (50 percent of those acquired after 2000). Some of this stock, e.g. one's/partner's own home or inherited property, becomes let out for the short-term. Our eight participants who engaged in 'accidental' landlordism (four in the past and four at the time of data collection) did so for different reasons and circumstances:

- Two participants (aged 35/54) were not inclined to sell below their desired price; and their good economic (and 'credit') capital allowed them to move up the housing ladder without using their accrued equity. Given subsequent positive letting experiences, these 
participants were considering remaining longer in the PRS until the accrued equity in the rented property would clear their own mortgages.

- One affluent, early-retired participant (aged 58) with a housing career consisting of seven residential moves (1978-2010) had repeatedly let out a previous home until the sale was concluded. While he indeed practiced 'homeownership-based welfare' and accumulated significant wealth in his own home with a view of downsizing, he had never engaged in letting as an investment strategy.

- Another four participants (aged 32-58) alternated both planned and unplanned spells of landlordism along active self-developing housing careers in order to achieve early outright homeownership with a view of downsizing (two in the past; two at the time of data collection). Their strategic focus was moving up the property ladder with letting out (or renting for short periods) being circumstantial.

Data therefore show diversity among these more or less 'accidental' landlords whose most defining characteristic is being in the PRS for a short time. Their housing careers indicate a tangential nexus between homeownership and landlordism. A key point to emphasise, however, is the privileged social position of these short-term landlords who could afford to move without selling (and of some other homeowners in our larger sample who could afford to move by selling at a loss) compared to that of many 'captive' homeowners who had to stay put in an unsuitable home. Mr IN, our remaining participant who had previously let short-term in the past but planned to let strategically in the future, long lamented his decisions of navigating the housing markets:

Between 1995 and 1997, I owned my first house, a small terraced house; then I owned between '97 and 2000, a nice semi-detached house in the North-East of England. Then in 2000 I moved to the Caribbean because I was working there [...] 
We rented our house out but the tenant wasn't very nice and we had a lot of trouble. My wife was very upset and said "I just want to sell the house". I sold the house in 2001 but in 2002 we had to return to the UK. Hard as it's to believe, I was thinking “well, I don't think property prices will go up that much more, it's ridiculous what they are now" and I thought we better rent until prices fall and I'll be in a better position to buy. And I was wrong! We rented for four years and in that time property prices trebled, basically! I bought this house for $£ 138000$ in 2006 and later we could only sell at a loss [...] So, that was the biggest single mistake I've ever made in my life, unfortunately and now I'm literally paying for it. I mean basically the decision to sell rather than rent in 2001 and to rent rather than buy in 2002 has affected everything. Otherwise I would've been in an excellent position now; I would've been able to move to a better house with my family. But because I didn't, we're going to be stuck here for a while. It does get you down as we both work hard. (Male 41, £60-100k, past and prospective landlord)

\section{Betting on Capital Gains: 'Property Ladder' Strategies}

While letting out a property short-term between residential moves, particularly in depressed housing markets, is not unexpected for those who can afford it, our research evidenced new strategic practices. Rather than using their accrued equity to reduce debt on the next purchase, an increasing number of homeowners aim to keep it for renting purposes with expectations of accruing capital gains. This is a significant reinterpretation of the metaphoric concept of the 'housing ladder' as one aims to move up by keeping both feet on the ladder, each on a different rung. It also draws attention that landlordism is partly emerging as an extrapolation of the orthodoxy of homeownership. 
Four participants in our sample engaged deliberately in 'property-ladder' strategies (aged 31-37). They were not necessarily more affluent than some homeowners who preferred to sell their homes in order to reduce mortgage debt, but they chose to build up wealth almost exclusively through property. They lived austere lives and had crucial (though not necessarily significant financial) family support:

I overpaid like hell on our first mortgage! It was $£ 750$ and we overpaid another $£ 750$. When we bought our second property we'd demonstrated we could afford bigger payments even if our salaries didn't prove it. We live quite frugally, no flash holidays, don't eat out! And I drive a 17 year old Volvo! Didn't leave home till 28, didn't marry till 31, didn't start having children till 34. Life delayed but we're better off now. (Female 34, £30-40k, one property)

Our study suggests that such austere dispositions were strongly connected with first-generation social mobility, which links to Bourdieu's $(1984,2005)$ argument on the dynamics of social space. For example, the following quotation shows how property and landlordism may serve as mechanisms for transforming embedded cultural capital (DIY skills) and social capital (family support) into economic capital:

My dad has helped me a lot, he's a plumber and generally good at stuff so I've been able to buy rundown places and add value to them, which has helped me get the next deposit. Without my dad, it would either have been a lot more expensive or a lot slower. As I said, I bought a fixer-upper. I borrowed £3k off my parents when I bought my first place, otherwise I've had no direct financial help, but that was invaluable. (Male 31, £60-100k, two properties) 
Two other participants' engagement in landlordism was facilitated by partnership formation. Rather than improving their housing circumstances by pooling resources, these people opted for long-term letting because they saw property as the best way to invest and finance retirement. Crucially, they appreciated the control and flexibility of property investment, which are denied by classic pension schemes:

I consider the flat that I've got, the flat I let out, that I've got as my pension. Any extra money that I get that I will save for my future will go into things within my own control. And I understand I have to pay tax on that and I am not sheltered in any way from it... "Within my control" is the key phrase! (Male 49, under $£ 15 k$, one property)

It could be argued that such testimonies indicate the internalisation of the pervasive neoliberal discourses of individualisation, risk-taking and choice (Langley 2006). Obviously, there is a potential tension between the dual role of property investment as a means for investment for long-term and safety-net needs, particularly in a wealth portfolio highly skewed towards property. But most homeowners have similar risks; our landlords emphasised that by comparison, their own homes remained protected from a need to liquidate housing wealth:

If you own more than one property then you are a bit safer with your own home, because you can sell it and still have somewhere to live. Meanwhile, the rent covers the mortgage plus a bit more. So the flat pretty much takes care of itself. Our tenant set up a direct payment, so he can't forget to pay the mortgage, it comes in automatically. (Male 35, £50-60k, one property)

The above rent/mortgage slip-of-the-tongue shows interesting interdependency between tenants/landlords in the latter's pursuit for capital gains. This symbiosis structures a large part of the PRS - 64 percent of dwellings held by landlords being acquired with a mortgage (DCLG 
2011) — and it frames the prevalent rent metaphor as 'paying someone else's' mortgage' (Gurney 1999; Soaita and Searle 2016). Our participants calculated neither rates of returns nor yields; it was belief in capital gains rather than book-keeping that energised their practices. However, such tightly-operating landlords may become vulnerable to (prolonged) vacancy/arrears and may temporarily need to subsidise their letting activities from their own income (Beatty et al. 2014; Wallace and Rugg 2014).

Combining Capital Gains and Rents: 'Why-not' investing?

'Property-ladder' strategies may be used to asset-build as a base for future welfare, however, three participants entered the PRS recently just because 'everybody does it' (aged 53-62, all on $£ 60-100 \mathrm{k}$ ). The (mis)belief that 'everybody does it' clearly indicates homophily ${ }^{14}$ in participants' positions in the social space and corresponding social networks-meaning 'everybody I know does it'-but perhaps also the anticipation that 'everybody who can does it'. In these three cases, the rental property was bought deliberately $(n=1)$, acquired by inheritance $(\mathrm{n}=1)$ and perhaps most interestingly by downsizing into two adjacent terraced homes $(n=1)$. Having good pension plans but not yet retired, these participants saw their small rental portfolios as an alternative savings account to be passed to their children-crucially, offering higher returns than the negligible ones in the financial markets, as many participants highlighted: ${ }^{15}$

The property will go to my son [a mortgagee]... but we haven't thought that longterm about it. It brings an income but not to use myself, about $£ 1700$ a year income... Well that income gets saved at the moment, I don't need it really... it's just an investment for my son. (Male 52, £60-100k, half property) 
Both 'property-ladder' and 'why-not' landlords in our sample entered the PRS between 2008 and 2013. This is highly suggestive for the ways in which engagement in landlordism is linked to the macroeconomic environment, particularly low interest rates and lower house prices. Our research shows that the attraction of rental property investment is likely to continue, ceteris paribus, with more individuals planning to become landlords in the near future.

\section{Like Moths to a Light: Prospective Landlords}

As noted earlier, Lord et al (2013) showed that the number of landlords in Britain trebled reaching three percent of the adult population; however three times more individuals aspire to landlordism. In our study, nine participants planned to become landlords in the near future: five by upsizing (aged 25-37), one by downsizing (aged 51) and three by means of inheritance (aged 36-53):

My long-term dream is to save up the deposit, and it probably won't happen at the moment but it would be good to be able to build a deposit for a second property, a house for my future, and then letting the flat out because it's a rentable flat, it will bring in profit for me! I want to build up financial security, that's my thing! (Female 25, £15-30k, homeowner)

Some of these prospective landlords may be wishful thinkers, as Miss FH above, though having the drive/disposition is itself telling about the performative power of the nexus between homeownership and landlordism. But the others were not. For instance, at first glance, Mrs AC (aged 25) and her partner may qualify as wishful thinkers since they still lived in the parental home; however, they were in the process of buying their first 'fixer-upper' home and searching for another 'add-value' project to be let out. Ready to engage in two self-developing projects, they relied primarily on family support (DIY skills and living in the parental home). 
Three affluent participants' aimed to diversify their wealth portfolio either through means of inheritance or by downsizing into two properties. For instance, Mr MW, sole offspring (aged 53, >£100 000 household income) planned to rent out his mother's property (upon her passing) rather than buying purposefully 'as everybody does it' (sic). Likewise, Miss LB, sole offspring, a RtB mortgagee (aged 46, £30-40k,) planned soon to move her mother in with her, care for her in old age and let the maternal ex-Council home. This latter case illustrates what elsewhere has been referred to as strategies of 'refamilialisation' (Ronald and Elsinga 2012) but which include a landlordism component. While houses have been inherited for some time in the UK, although not at the extent initially expected (Hamnett 1999), the equity tended to be liquidated and divided among offspring. But since house values have skyrocketed, more individuals seem tempted to invest their inheritance share or to keep the tangible property for renting purposes (whether in sole ownership or in a trust).

However, a negative change in personal circumstances may expose any small-portfolio landlord whose wealth is highly skewed towards property to risks from vacancy, tenants' arrears or requirement for repairs. On the flip side, this could expose their tenants to a sudden sale, repossession, and/or poor housing quality.

\section{The Safety-Net of Rental Income: Strategies of 'Basic Subsistence'}

So far we have explored strategies of asset-building for future welfare, however, among our participants, some faced adverse economic shocks and turned to their housing wealth as a safety-net. Four respondents were relying almost exclusively on rental income at the time of data collection (aged 49-58, all $<£ 15000$ household income). Three of them used to run small, successful businesses in architecture, transport and real estate when they acquired a second property as business premises $(n=2)$ or a second home $(n=1)$. Affected by economic crisis and divorce (one also admittedly by overspending on 'high days and holidays'), they had to rent 
out as a safety-net. The fourth participant deliberately engaged in landlordism as a project of social mobility which involved a three-generation family. Mrs DB took the RtB for her own and parental council homes (in 1988 and 2000, respectively), the latter being already transferred into a rental trust for her four mortgagee children; as she became permanently disabled, Mrs DB was using the rental income to supplement state benefits. Given the centrality of rental income, these participants expressed a particularly deep attachment to their rental properties that may seem intrusive to tenants:

I went there yesterday; I wanted to look round to make sure the tenants were looking after my house. I still feel attached to it like a father to a child, that kind of thing. I want to make sure they don't damage anything, or it looks nice, and it looks clean... And I think that's important and that matters to me and I'm pleased to say that is the case at the moment. So, I'm happy. I feel I can rest more easily knowing that my property is being looked after because I feel an attachment to it. (Male 55, $<£ 15 \mathrm{k}$, one property)

While most of our active landlords with small portfolios $(n=15)$ fully endorsed the approach of ABW through property ownership, only two resented the inequalities created between property-haves and property-have-nots:

So, yes, I am using houses as a means to a living, which a lot of people fundamentally may disagree with. I think part of the problem is that we use housing as a means to make capital. It would be a fairer system if it was some other way for example, if there were better pensions or better support from the government. It would be better because it would be fairer. If you rely on housing for your support for the future or for your children, then obviously the people who have the houses will benefit more than people who don't. And therefore you create a divide in 
society for people who have and people who haven't. (Male 58, bellow $£ 15 k$, one property)

The quotation above raises key social policy questions on which we reflect in the conclusions after we discuss next the property circumstances, intentions and strategies of our large-portfolio landlords.

\section{Large Rental Portfolios}

Only 12 percent of all landlords own three or more properties in GB (Lord et al. 2013). In our sample, seven participants held between 3 and 13 properties (aged 50-65). These participants run their letting activities as businesses. Except one inheritor, they were self-made millionaires holding a balanced wealth portfolio across savings, shares, property and pension. As purchasers of various types of insurance protection, advised by professional accountants, and members of landlords associations, they again emphasised that one's own home should not be conceived of as a safety-net resource:

Maybe something that people need to think about is keeping the wealth of the property separate to the wealth needed for... yeah, for any situations that you don't know might occur. The rental property helps doing this, saves your home. (Female $46, £ 60-100 \mathrm{k}, 3$ properties)

We differentiated between strategies of established, low-debt operations ( $n=4$, portfolios of 36 lets, aged 50-65) and those of highly-financialised expansion ( $n=3$, portfolios of 3-13 lets, aged 46-55). Landlords employing the former acquired their properties from the early 1990s; they bought with cash from savings or income from their own businesses (the inheritor's portfolio was likewise developed by her father). Interestingly, while living with parents, one 
participant first purchased with cash three lets before buying his own home. Their letting activities, although important, were nonetheless secondary to their business preoccupations (except the inheritor though this applied to her father). They preferred long-term tenants and did not necessarily look to expand their portfolio unless strategically (e.g. to own a whole building).

While these established landlords tended to be financially very resilient, the inheritor Mrs WW (aged 60, £15-30k, 6 properties), a redundant teacher, was cash-poor/property-rich. Having paid $£ 840000$ inheritance tax in 2002 , she and her sister clearly inherited a large estate, including a trust of 14 lets. To her initial seven-property share, Mrs WW added an extra one in 2003 (financed by an interest-only BtL mortgage) but had to sell two inherited flats in order to finance major refurbishments required by the Council. The intersection of labour and housing markets increased her difficulties:

My job disappeared and I am only 60. I don't get my state pension... so things are a bit difficult. I couldn't survive without my rental income. Also part of my pension plan has been that I was going to sell the flat I bought. Unfortunately I missed the boat because... It had rocketed in value but last summer when I was thinking about selling, when I had it valued it was nowhere where it had been two years before, which is why I decided to hang on... I bought with a view to making money and I don't want to be the only person in the history of the world who lost money on a flat on B Road!

Conversely, the three participants engaged in highly-financialised portfolio expansions entered the PRS after 2000. They uniquely declared their profession as landlords; they tended to acquire property by BtL interest-only mortgages; and prefered $\mathrm{HMOs}^{16}$ — for 'rent extraction is more efficient'-situated in strategic locations where property 'doubles in price every five to seven 
years' enabling them 'to suck out money from the property' in order to finance a new purchase (Mr PL 55, >£100k, 12 properties). The golden rule, as Mr PL explained in detail using personal and theoretical examples, was that capital gains should about equal mortgage debt for he was interested exclusively in rental income-hence an ever expanding portfolio:

So for instance, I bought a property in London for a quarter of a million, in five years it's doubled in value. My mortgage on that is $£ 350,000$ [he re-mortgaged and bought another property], my rental on that is $£ 2,500$ per month, $£ 800$ per month is the mortgage, insignificant... So I've no intention of paying them off and any investor wouldn't look to pay off the mortgage.

Mr PL started his rental portfolio in 2005 and by 2013 had 12 properties but, as the other two respondents, planned to expand assertively given advantageous historically low interest rates, lower house values, and available mortgage products (while still keeping a balanced wealth portfolio across different asset classes). While all landlords' balance sheets will be affected by the changing regulatory landscape in the UK — an extra three percentage points stamp duty on BtL purchases and some restrictions in mortgage interest deductions - these participants' expansion strategies are particularly likely to be exposed.

Besides deciding 'to create his own pension vehicle', Mr PL's motivation to engage in the PRS draws attention to Piketty's (2014) alarming signal regarding the historic re-emergence of a 'rentier class' through, but by no means exclusively, ownership of rental property:

I was a director of a couple of software houses... But after a period of time I realised I was running too fast and had no time. As much as I had a big package, I had no time so what I wanted to change that so that I had more time but still a big package. Property does that for you! 
Indeed, rental income enabled two participants (aged 50/60, >£100k, portfolios of 5-6 lets) to take a 5-year career break and early retirement in order to take on full-time care of both parents and a disable wife, respectively.

Crucially, horizontal inequalities are increasingly being passed down the family generations via homeownership but even more intensively via landlordism. While many participants' engagement in small-scale landlordism was supported by their family, for example significant DIY, extended living in the parental home or by complex refamiliarisation strategies, they rarely had significant financial support. Yet our affluent landlords offered critical financial support for their children to engage early in homeownership/landlordismeven though they preferred to emphasise the transmission of knowledge and family dispositions (habitus) rather than that of economic capital, as explained below (this was also true for three small-portfolio participants whose parents were landlords):

Our children have a similar "investment in property" mentality! For example when my children went to university, I enabled them to buy houses that they let out to fellow students and covered their mortgage that way. So if you like, my knowledge about property and renting was passed on to my daughters at a very early age! And now, they're wealthy, they're wealthy in terms of assets as a result of that. (Male $65,>£ 100 \mathrm{k}, 13$ properties)

There was evidence that landlords' motivations to engage in letting activities and their property-based welfare and investment strategies were not patterned by geography. But the wealth from their rental portfolio was, reflecting known differentials in local and regional housing markets. For instance, a six-property portfolio based in the South-East may be worth as much as an 11-property one in the North-East (Nationwide 2015). Interestingly, our analysis shows that if geography did not affect landlords' motives and strategies, geographical 
proximity to the rental properties did. With the exception of one landlord whose large portfolio dispersed across 470 miles - which interestingly mirrored his children's educational trajectories - our participants clearly appreciated proximity to their rental properties given ease of property management. This indirectly supports Wallace's and Rugg's (2014) findings: 9 out of 10 landlords with geographically dispersed portfolios were discontented given management difficulties. Furthermore, when participants bought purposefully to let out, they bought in the immediate proximity (same building, neighbourhood or regional market); homeowners who moved a considerable distance preferred to sell rather than renting out.

Finally, we end this section observing that almost unanimously_-whether of small or large portfolios, whether they were ex, actual or prospective landlords-participants believed in the long-term security of property investment:

Property is not a risk. House prices have never dropped over a long period of time, they might drop over a short period of time but never over a long period of time. Because this country faces a tremendous shortage of housing which is going to take a long time to fix, is my view.' (Male $65,>£ 100 \mathrm{k}, 13$ properties)

Caution was expressed by a few:

If you're going to rely on houses to be your pension or security for family generations I think you're massively relying on timing of the economy, of so many different things you can't control... Each house is going to be worth different amounts at different times, higher or lower. If you're pinning your world on retiring at this age and selling your house at this much, I think it may be a dodgy position to put yourself into. (Male 32, £60-100k, past landlord) 


\section{Conclusions}

This paper explored peoples' motivations to engage in landlordism and the ways in which their property-based welfare strategies were shaped by the intersection of individual socioeconomic and life-course circumstances, and the broader socioeconomic and financial environment. On the one hand, we differentiated between landlords' investment aim (or lack of it) of relying on capital gains, rental income or both. On the other hand, we differentiated between small and large rental portfolios. By combining these criteria, we offered a more nuanced understanding of the different ways that ABW strategies operate within the PRS. Our approach allowed us to highlight how landlords imagined their property wealth as a source of welfare in specific (albeit potentially fluid) ways, which were linked to their personal circumstances. Property wealth was used as immediate income and as a savings account by some, or imagined as future capital gains by others. Investing in the PRS was a way of diversifying large wealth portfolios by a very privileged few, or a prime asset-building vehicle for financing retirement and a safety-net for others. Indeed, a few participants had to rely on rental income for basic subsistence.

Landlordism was viewed differently by small- and large-portfolio landlords. Regarding the former, our study draws attention to an understudied nexus between homeownership and landlordism according to which the latter can be seen as an extrapolation of the former in two important ways. First, by beliefs - and substantiating this point is our main theoretical contribution (rooted in our ontological and epistemological perspectives of the social world). The internalised confidence in ever-increasing house values, which turned homes into assets (Soaita and Searle 2016), is extrapolated from the owner-occupied home to rental property. The tangibility, familiarity and confidence in long-term profit through capital gains make engagement in landlordism sine-qua-non attractive and book-keeping redundant. Second, by separating what otherwise may be dangerously combined: as the long-term financial benefits 
of homeownership are extrapolated to landlordism, short-term risks are mitigated. While landlordism was seen as a long-term ABW strategy, it was also conceived as a safety-net. Landlords felt privileged since they could liquidate the wealth in their additional property without jeopardising the sanctity of their own homes.

Most small-portfolio landlords saw property as a key means of accumulating wealth and a major vehicle of financing retirement. Besides expecting continuing growth in house values, other factors grounded their decisions, particularly secure demand for PRS tenancies, poor savings rates, accessible BtL mortgages and last but not least, their privileged possession of capital. Bourdieu's (1985) conceptualisation of different forms of capital has been key to understanding how rented property may be used as an instrument of social mobility as well as a cushion for those finding themselves on downward social trajectories, particularly in the field of employment. We showed that not only household income mattered, for this varied greatly among participants, but also the overall mix of social capital (family and partners, but also friends); embedded cultural capital (e.g. 'investment mentality' and DIY skills); and of course parental economic capital whether in terms of financial support for home purchase, homeliving in order to save, or childminding. We should also reflect on the innate disadvantages of those without parental support, singles and females who are less likely to be able to combine all these forms of capital in order to access homeownership and/or landlordism.

This close nexus between homeownership and landlordism was not evidenced in the case of large-portfolio landlords, who endorsed a business outlook. Long-established landlords' property affinities directed them into letting as a sideline business activity since the 1990s whereas those who practiced highly-financialised ways of expansion after 2000 aimed to finance a very comfortable lifestyle primarily through the flow of rental income. All but one (the inheritor) matched the profile of the sophisticated investor (Langley 2006), managing risks across a balanced portfolio of liquid assets (savings and shares), property and pensions. Their 
economic capital placed them in the top deciles of wealth distribution in the UK (ONS 2014). As accumulating capital takes time, there were expected life-course and cohort differences between small- and large-portfolio landlords even when significant financial and cultural capital was passed down the family generations. Clearly, property-ladder strategies may build up large portfolios, particularly by leveraging the accrued equity to purchase additional property.

The particular interactions between individual circumstances and the economic, labour and housing cycles created both positive and negative synergies. Entering landlordism following partnership formation is an example of the former whereas selling for not being able to finance refurbishment after redundancy exemplifies the latter. Our constructivist grounded analytical approach (Charmaz 2014) was particularly useful in highlighting the complex ways in which meanings and beliefs, access to various sources of capital, circumstantial events, and life-course trajectories result in particular property-based welfare strategies.

Our study has, however, limitations. Given our incidental sampling, further research is needed to fully document landlords' diverse property-based investment and welfare strategies. For instance, we have not observed practices of 'Mum and Dad' investors buying nearby properties as future homes for their children (Bierre et al. 2009; Hulse and McPherson 2014). Many recent changes that will clearly affect the nature of landlordism require future research, for instance the effects of 2015 'pension freedom' reform (possibility to withdraw large lumpsums); those of fiscal changes in the treatment of rented dwellings (higher transaction tax and reduction in mortgage interest relief); the consequences of potential interest rate increases; and last but not least the unknown corollary of the recent EU-exit vote. We argue that an important route to theorising such changes via qualitative research — both within the UK and beyond - is to further scrutinise the (under-theorised) nexus between homeownership and landlordism, which we have substantiated in this paper. 
Our exploratory study shows that many landlords aimed at expanding their rental portfolios. This may have two contradictory consequences. On the one hand, our study suggests that large-portfolio landlords tended to be financially more resilient and thereby theoretically able to provide better dwellings and more secure tenancies. But on the other hand, housing markets were shown to reinforce existing wealth inequalities across socioeconomic groups, cohorts and geography. Landlordism magnifies this effect particularly when the concentration of housing wealth occurs as redistribution within the existing housing stock as is currently the case (70 percent of dwellings having been acquired as such). While landlords provide an increasingly crucial tenure for many, striking the balance between these two concerns is undoubtedly informed by political/ideological choices. Some timid steps have been taken in England and Scotland regarding the fiscal treatment of residential properties, which includes higher tax rates for ownership of second properties (whether rented out or not); Scotland went further with the 2016 'Private Housing (Tenancies) (Scotland) Bill' which inaugurated a form of secure and flexible tenure for tenants while maintaining landlords' rights to sell/occupy the dwelling at any time.

However, our study's key policy contribution is to draw attention to the fact that housing in general, and the PRS in particular, sits uneasily at the intersection of a housing system under pressure and the (neoliberal) individualisation of welfare provision. The very high heterogeneity in landlords' circumstances is a consequence of property being positioned as an $\mathrm{ABW}$ strategy. This challenges not only the possibilities of finding better ways to harmonise the wellbeing and welfare of those providing and those needing a privately-rented home, but indeed the very sustainability and fairness of the shift between systems of collective versus individual welfare provision. Therefore, we add our voices to other scholars (Doling and Elsinga 2012; McKee 2012; Ronald and Elsinga 2012; Smith and Searle 2010) who demand reanalysing the links between housing and welfare in order to construct a new social 
contract between citizens, markets and the state. Key housing policies include stimulating newbuilt, tenure-neutral housing and regulating the PRS (including rent capping in pressured areas). But housing policies should be paralleled by key fiscal and monetary policies, particularly a thoroughly reconsidered, consistent and fair treatment of housing wealth and housing costs across tenures (e.g. capital gains, imputed rents, Council tax and the like); ending current policies of historically-low interest rates; and stimulate the design of rewarding savings products.

\section{Acknowledgements}

We thanks to the three anonymous referees whose insightful comments help us substantially improve this paper. This work was supported by the Leverhulme Trust under Grant RP2011IJ-024.

\section{References}

Ball, M. (2010) The UK Private Rented Sector as a Source of Affordable Accommodation, York: Joseph Rowntree Foundation.

Barker, K. (2004) Review of Housing Supply. Delivering Stability: Securing our Future Housing Needs, Norwich: HMSO.

Beatty, C., Cole, I., Powell, R. \& Sanderson, E. (2014) Monitoring the Impact of Recent Measures Affecting Housing Benefit and Local Housing Allowances in the Private Rented Sector: The Response of Landlords, London: Department for Work and Pensions.

Bhaskar, R. (1989) The Possibility of Naturalism: A Philosophical Critique of the Contemporary Human Sciences (London: Harvester Wheatsheaf). 
Bierre, S., Howden-Chapman, P., and Signal, L. (2009) 'Ma and Pa' landlords and the 'risky' tenant: discourses in the New Zealand private rental sector, Housing Studies, 25(1), 2138.

Boudon, R. (2001) The Origin of Values: Essays in the Sociology and Philosophy of Beliefs (New Jersey: Transaction).

Bourdieu, P. (1977) Outline of a Theory of Practice (Cambridge: Cambridge University Press).

Bourdieu, P. (1984) Distinction: A Social Critique of the Judgement of Taste (London: Routledge).

Bourdieu, P. (1985) The forms of capital, in J.G. Richardson (Ed) Handbook of Theory and Research for the Sociology of Education (New York: Greenwood), 241-58.

Bourdieu, P. (1989) Social space and symbolic power, Sociological Theory, 7(1), 14-25.

Bourdieu, P. (1990) The Logic of Practice (Stanford: Stanford University Press).

Bourdieu, P. (1998) Practical Reason: On the Theory of Action (Stanford: Stanford University Press ).

Bourdieu, P. (2005) The Social Structures of the Economy (Cambridge: Polity Press).

CCHPR (2012) The Private Rented Sector in the New Century-A Comparative Approach, Cambridge Centre for Housing and Planning Research.

Charmaz, K. (2014) Constructing Grounded Theory (London: Sage).

Clarke, B. (2016) Buy-to-let reforms should reflect wider market conditions, lenders say, (London: Council of Mortgage Lenders).

Cramer, R. \& Shanks, T.R.W. (Eds) (2014) The Assets Perspective: The Rise of Asset Building and Its Impact on Social Policy (New York: Palgrave Macmillan).

Crook, T. \& Kemp, P.A. (2010) Transforming Private Landlords: Housing, Markets and Public Policy (London: Wiley-Blackwell). 
DCLG (2010) Housing Wealth Inequality, Department for Communities and Local Government.

--- (2011) Private landlords survey 2010, Department for Communities and Local Government.

Doling, J. \& Elsinga, M. (2012) Demographic Change and Housing Wealth: Home-owners, Pensions and Asset-based Welfare in Europe (London: Springer).

Doling, J. and Ronald, R. (2012) Meeting the income needs of older people in East Asia: using housing equity, Ageing and Society, 32(3), 471-90.

Dorling, D. (2014) All that is Solid: the Great Housing Disaster (London: Allen Lane).

Esping-Andersen, G. (1990) The Three Worlds of Welfare Capitalism (Cambridge: Polity Press).

Flint, J. (2003) Housing and ethopolitics: constructing identities of active consumption and responsible community, Economy and Society, 32(4), pp. 611-629.

Fox, L. (2007) Conceptualising Home: Theories, Laws and Policies (Portland: Hart Publishers).

Fox O'Mahony, L. \& Overton, L. (2014) Asset-based welfare, equity release and the meaning of the owned home, Housing Studies, 30(3), pp. 392-412.

Gorski, P.S. (Ed) (2013) Bourdieu and Historical Analysis (London: Duke University Press).

GOV.UK (2016) Live tables on dwelling stock (02.07.2016).

Gurney, C.M. (1999) Pride and prejudice: Discourses of normalisation in public and private accounts of home ownership', Housing Studies, 14(2), 163-83.

Hamnett, C. (1999) Winners and Losers: Home Ownership in Modern Britain (London: UCL Press).

Hills, J., et al. (2013) Wealth in the UK: Distribution, Accumulation, and Policy (OUP Oxford). 
Hills, J., et al. (2010) An anatomy of economic inequality in the UK: Report of the National Equality Panel London: Government Equalities Office. Centre for Analysis of Social Exclusion, The London School of Economics and Political Science.

Hughes, D. \& Lowe, S. (Eds) (2007) The Private Rented Housing Market: Regulation or Deregulation? (Aldershot: Ashgate).

Hulse, K. \& McPherson, A. (2014) Exploring Dual Housing Tenure Status as a Household Response to Demographic, Social and Economic Change, Housing Studies, 29(8), pp. $1028-1044$.

Kemeny, J. (1981) The Myth of Home Ownership: Private versus Public Choices in Housing Tenure (London: Routledge).

Kemp, P.A. (2015) Private renting after the global financial crisis, Housing Studies, pp. 1-20. Langley, P. (2004) In the eye of the 'perfect storm': the final salary pensions crisis and financialisation of Anglo-American capitalism, New Political Economy, 9(4), pp. 539558.

Langley, P. (2006) The making of investor subjects in Anglo-American pensions, Environment and Planning D: Society and Space, 24(6), 919-934.

Langley, P. (2009) Debt, discipline, and government: foreclosure and forbearance in the subprime mortgage crisis, Environment and Planning A, 41(6), 1404-19.

Lloyd, J. (2013) Whose home? Understanding landlords and their effect on public policy, London: Strategic Society Centre.

Lloyds Bank (2015) Downsizing windfall rises to over $£ 100,000$ in 2014, London: Lloyds TSB.

Lord, C., Lloyd, J., \& Barnes, M. (2013) Understanding landlords. a study of private landlords in the UK using the Wealth and Assets Survey, London: Strategic Society Centre.

Malpass, P. (2005) Housing and the Welfare State: The Development of Housing Policy in Britain (Basingstoke: Palgrave Macmillan). 
McKee, K. (2012) Young people, homeownership and future welfare, Housing Studies, 27(6), 853-62.

McKee, K. (2015) An introduction to the special issue - The Big Society, Localism and Housing Policy: Recasting State-Citizen Relations in an Age of Austerity, Housing, Theory and Society, 32(1), 1-8.

Nationwide (2015) Nationwide: House Price Index Available at <http://www.nationwide.co.uk/about/house-price-index/downloaddata\#tab:Downloaddata> (accessed 26 August 2015).

NLA (2013) More than a third of landlords struggle to pay their bills when tenants miss payments, News \& Campaigns National Landlords Association, November 8.

ONS (2014) Property Wealth, Wealth in Great Britain 2010-12, ONS digital: Office of National Statistics.

http://webarchive.nationalarchives.gov.uk/20160105160709/http://www.ons.gov.uk/o ns/rel/was/wealth-in-great-britain-wave-3/2010-2012/report--chapter-3--propertywealth.html

Paragon (2013) UK private rented sector and buy-to-let market 2013, London: Paragon.

Ronald, R. (2008) The Ideology of Home Ownership: Homeowner Societies and the Role of Housing (Basingstoke: Palgrave Macmillan).

Ronald, R. \& Doling, J. (2012) Testing home ownership as the cornerstone of welfare: lessons from East Asia for the West, Housing Studies, 27(7), pp. 940-961.

Ronald, R., Lennartz, C., and Kadi, J. (2015) What ever happened to Asset-based Welfare? Shifting approaches to housing wealth and welfare security, HOUWEL Working Papers Series No7 (University of Amsterdam).

Ronald, R. \& Elsinga, M. (Eds) (2012) Beyond Home Ownership: Housing, Welfare and Society (Abington: Routledge). 
Rugg, J. \& Rhodes, D. (2003) 'Between a rock and a hard place': the failure to agree on regulation for the private rented sector in England, Housing Studies, 18(6), pp. 937946.

Ruonavaara, H. (2012) Tenure as an institution, in: S.J. Smith (Ed) International Encyclopedia of Housing and Home, pp. 185-189.

Scanlon, K. \& Kochan, B. (Eds) (2011) Towards a Sustainable Private Rented Sector: The Lessons from Other Countries (London: LSE).

Swartz, D.L. and Zolberg, V.L. (Eds) (2004) After Bourdieu: Influence, Critique, Elaboration (New York: Springer).

Schwartz, H.M. \& Seabrooke, L. (Eds) (2009) The Politics of Housing Booms and Busts (London: Palgrave Macmillan).

Searle, B.A. \& McCollum, D. (2014) Property based welfare and the search for generational equity, International Journal of Housing Policy, 14(4), 325-43.

Smith, S.J., Searle, B.A, \& Cook, N. (2009) Rethinking the risks of home-ownership, Journal of Social Policy, 38(1), 83-102.

Smith, S.J. \& Searle, B.A. (Eds) (2010) The Blackwell Companion to the Economics of Housing: The Housing Wealth of Nations (London:Wiley-Blackwell).

Soaita, A.M. \& Searle, B.A. (2016) Debt amnesia: homeowners' discourses on the financial costs and gains of homebuying, Environment and Planning A, 48(6), 1087-106.

Toussaint, J. \& Elsinga, M. (2009) Exploring 'Housing Asset-based Welfare': can the UK be held up as an example for Europe?, Housing Studies, 24(5), pp. 669-692.

Wallace, A. \& Rugg, J. (2014) Buy-to-let mortgage arrears: understanding the factors that influence landlords' mortgage debt York: Centre for Housing Policy. 
1 The share of the PRS (versus the share of the social rented sector shown in brackets) was $19.8 \%(17.4 \%)$ in England; $16.9 \%(16.2 \%)$ in Northern Ireland; $15.5 \%$ (23.5\%) in Scotland; and $14.0 \%(15.9 \%)$ in Wales.

2 Paragon (2013) argued there were 3,648 BtL products on offer in 2007 but only about 478 in March 2013. There were 346,000 BtL mortgages completed in 2007; this fell to 88,400 in 2009 but increased to about 300,000 in 2012

${ }^{3}$ See, for instance, Gorski (2013) and Swartz and Zolberg (2004) on the growing reconciliation between Bourdieu's relational view of the world and fundamental interpretative, realist and social-constructivist epistemological and ontological tenets.

4 They drew on the Wealth and Asset Survey, wave 2 (2008-10). More info: http://www.ons.gov.uk/ons/media-centre/statements/the-wealth-and-assets-survey/index.html

5 This draws on the Private Landlord Survey 2010 in which about 1,000 landlords and agents were interviewed. More info: https://www.gov.uk/government/collections/private-landlordssurvey

6 We also draw on two other major studies. One explored landlords'/agents' views in GB in relation to the post-2010 reduction in housing benefits (Beatty et al 2014; Kemp et al 2014). The other focused on BtL landlords at risk of mortgage arrears (Wallace and Rugg 2014). Additionally, ARLA's (2014) quarterly landlords' web surveys conducted between 2010 and 2014 presented the views of about 1,000 landlords across the UK.

${ }^{7}$ Out of all PRS dwellings, 64 percent were bought with a mortgage; 26 percent with personal savings or income from business; and 10 percent were inherited. Overall, 72 percent were acquired with an intention to let and 14 percent were previously inhabited by the landlord. 
Likewise less than one percent owned over 100 lets but they controlled 11 percent of the stock.

9 But only one in 2,500 were in mortgage arrears (Clarke, 2016).

10 These were located in Northern Ireland (Belfast), Wales (Merthyr), England (Cornwall, Surrey and Sheffield) and Scotland (North Lanarkshire, the Scottish Borders, and Edinburgh).

${ }^{11}$ We obtained permission to contact 539 individuals who took part in the 2012 FRS and expressed an interest in participating in future research. We reached by telephone 297 individuals, out of who 112 were interviewed (the others declined; 38 percent response rate).

${ }^{12}$ But 35 instances of past, actual or planned landlordism since one participant was both a past and prospective landlord. We were able to identify the 29 landlords aged 35-65 in a very consistent manner given that we asked early in the interview 'Do you own any (other) physical or financial assets?' probing for savings, pension, a car and rental property. All our following questions on the role of housing wealth were asked with reference to the participant's home and additional properties, thus gaining in-depth knowledge about participants' motives and circumstances of engaging in landlordism along with their housing histories. These interviews were conducted solely by the first author. Participants aged 18-35 were asked about ways of building financial security over the long-term through homeownership, property investment and other means (e.g. shares, pension funds). While questions were asked at the end of the interview/focus group, the five participants who engaged (or planned to) in landlordism did already make the point, describing their motives, intentions and experiences. This data collection was solely conducted by the fourth author.

13 DCLG (2011) also showed that only eight percent of landlords declared themselves as fulltime landlords. 
${ }^{14}$ The tendency of individuals to associate with others 'like us' i.e. in terms of one's capital endowment and shared values/beliefs.

15 As low interest on savings penalizes savers, some homeowners decided to move into larger residences. For instance, one single, male participant aged 60, owning a 'pretty ideal 3-bed detached house' decided to use $£ 150000$ (almost all his savings) in order to move-up into a 5bed detached house 'at least to enjoy money that otherwise stay idle in the bank'. Likewise, at his parents' insistence, one participant aged 37 (sole offspring) sold his 2-bed flat in order to buy with cash a 4-bed detached house and thereby 'protecting' his parents' $£ 190000$ savings.

16 HMOs stands for Housing in Multiple Occupation, traditionally representing shared living arrangements in the student market. Under recent housing benefit/allowance changes, single people under 35 are deemed to live in HMO accommodation. 